\title{
Effect of magnesium sources on dry matter yield and plant nutrients content of wheat (Triticum aestivum L.), barley (Hordeum vulgare L.) and maize (Zea mays L.) crops varieties
}

R. S. GARHWAL AND J. R. JAT

Received : 08.02.2017; Revised : 18.05.2017; Accepted : 26.05.2017

MEMBERS OF RESEARCH FORUM:

Corresponding author :

R. S. GARHWAL, Department of Soil Science, College of Agriculture, (C.C.S.H.A.U.), Kaul, KAITHAL (HARYANA) INDIA

Email: rsg.rca2011@gmail.com
Co-authors :

J. R. JAT, Department of Soil Science, C.P. College of Agriculture, (SDAU), Dantiwada, BANASKANTHA (GUJARAT) INDIA

\section{Summary}

A pot experiments were conducted during 2005-06 in Rabi seasons at MPUAT, Udaipur (Rajasthan) on the response of wheat, barley and maize varieties of magnesium sources on nutrients status of soils, dry matter yield and nutrient content under grown in clay loam and loamy sand soils. The highest content of Ca was observed under varieties GW-322 of wheat, RD-2035 of barley and Pratap M-5 of maize grown soils. More Mg was observed in varieties Lok-1 of wheat, RD-2624 of barley and Aravali M-3 of maize crops grown soils. The maximum $\mathrm{Fe}, \mathrm{Mn}, \mathrm{Cu}$ and $\mathrm{Zn}$ were observed in Lok-1 and Navjot varieties of wheat and maize grown soil. The highest $\mathrm{Mg}, \mathrm{P}, \mathrm{S}, \mathrm{Fe}, \mathrm{Mn}, \mathrm{Cu}$ and $\mathrm{Zn}$ content estimated with magnesium sulphate application soils while more $\mathrm{Ca}$ content was estimated in soil under application of dolomite. Lok-1(3.18 g/pot) varieties of wheat, RD-2645 (2.67 g/pot) of barley and Pratap M-5 (8.24 g/ pot) of maize were produced highest dry matter yield. Magnesium sulphate application in wheat, barley and maize crops significantly increased dry matter yield $(7.28,4.35$ and 2.94\%, respectively) over dolomite application. Dry matter yield significantly increased $(5.22 \%, 9.60 \%$ and $19.11 \%$ of wheat, barley and maize crops, respectively) with grown in clay loam soil than loamy sand soil. The concentration $\mathrm{Mg}, \mathrm{Fe}, \mathrm{Mn}, \mathrm{Cu}$ and $\mathrm{Zn}$ significantly higher were observed in variety Lok-1 of wheat and varieties RD-2592 of barley shoot tissue. While, highest $\mathrm{Ca}$ concentration was found in variety HI-8498 of wheat and variety RD-2552 of barley plant. However, maximum sulphur in variety Raj.3756 and RD-2624 of wheat and barley, respectively. Highest value of $\mathrm{Ca}, \mathrm{Mg}$ and sulphur content was found in maize varieties PHEM-2, Aravali Makka-1 and Pratap Makka-3 respectively, while, highest phosphorus, $\mathrm{Fe}, \mathrm{Mn}, \mathrm{Cu}$ and $\mathrm{Zn}$ content was found in variety Navjot. Ca content was observed significantly higher with application of dolomite grown crops dry matter.

Key words : Magnesium, Variety, Soil type, Nutrient status

How to cite this article : Garhwal, R.S. and Jat, J. R. (2017). Effect of magnesium sources on dry matter yield and plant nutrients content of wheat (Triticum aestivum L.), barley (Hordeum vulgare L.) and maize (Zea mays L.) crops varieties. Asian J. Soil Sci., 12 (1) : 210-216 : DOI : 10.15740/HAS/ AJSS/12.1/210-216. 